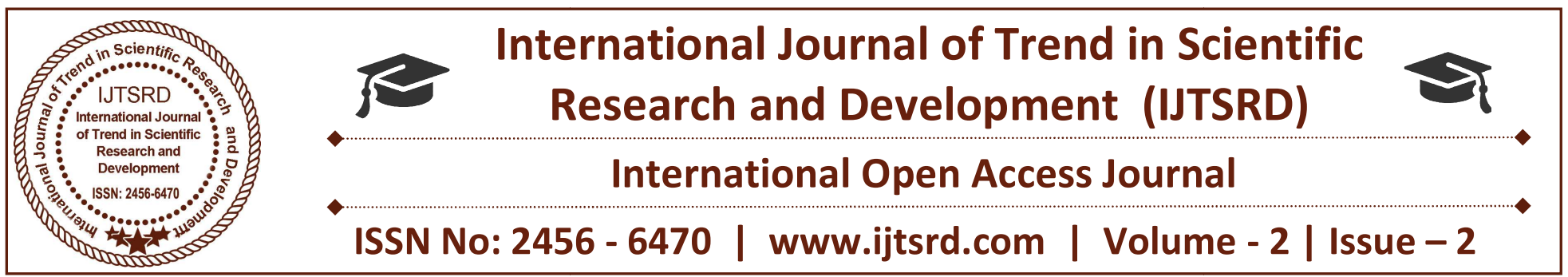

\title{
The Role of Extradition Treaties in Crime Management and Combating Terrorism
}

\author{
Adishi, Eric (Ph.D) \\ Department of Intelligence and Security Studies, \\ NovenaUniversity Ogume, Delta State, Nigeria
}

\author{
Oluka, Nduka Lucas \\ Department of Political ScienceNovena University \\ Ogume, Delta State, Nigeria
}

\section{ABSTRACT}

Many countries all over the world is enmeshed and grappling with the problems of crimes, threats and terrorism. These crime incidence have occurred with high level of intensities and fatalities that could be said that nations of the world have lost its cooperate existence, because solutions to these problems seems to be unabated as a result of international collaboration and the extradition treaties in combating these ugly menace which seems to be comatose. Hence, this paper examines and addresses the role of extradition treaties in management of crime and combating terrorism. The study critically examined the principles and processes of extradition and the general problems associated with it. The study uses comparative and qualitative analyses as its methodological components to x-ray the relationship between extradition treaties and global terrorism. Secondary sources of data become the hub of its methodology. The Dual/ Double criminality theory which has its root in the Jay Treaty of 1794 of the United States and Great Britain, popularized by Lech Gardodei in 1993, was used as its theoretical framework. The study revealed that some of these extradition treaties prevent punishment of protected persons. The study discovered that lack of synergy between extraditing countries constitutes impediments against the management of crime and combating terrorism. The study further found out that international political power game guiding extradition and management of crimes and combating terrorism impede transnational prosecution. The study recommended a strong political will among member nations in order to ensure compliance to extradition treaties and to combat terrorism globally.

Keywords: Extradition treaties, Crime, Terrorism, Global security challenges

\subsection{Introduction}

It is obvious that international crimes across borders or transnational crimes are on the increase. These crimes include human trafficking; money laundry, proliferation of small arms and light weapons to weapons of mass destruction, corruption, cyber warfare, insurgency and the worse scenario terrorism. These ugly situations have occurred with high rate of fatalities and are more rampant and pervasive in recent decades, which could be said that international bodies have lost the essence of their corporate existence as regard to the role of extradition treaties and punishment of fugitive offenders. In the last few years especially 9/11 attacks, the United States and other European nations have witnessed a rising shift from mere criminality to terrorism. And these terrorist acts are perpetrated from one country to another either in the name of religious extremism, economics sabotage, debacle, political interest or geographic affiliations, and the intensity of these conflicts or terrorist acts is being aided by a global network of fellows that cut across international borders to the extent that terrorism has been perceived as a two way context between a band of violent activists and a sovereign state which throws a spotlight on certain terrorist organization to promote their interest (David, 2004).This creates a rift or conundrum in the global 
security as nations are confused on how best to fight terrorism and crime globally. Hence, the establishment of extradition treaties which is an international law made globally or between two states in the treatment and prosecution of fugitive offenders.

The decision whether or not to extradite fugitive criminals or offenders including terrorists generally, and the methods adopted to extradite lies solely in the hands of the state from which the extradition is requested. In other words, when the requested state has made the decision to extradite the fugitive criminal or a wanted terrorist, extradition may take place depending on the position of the requested state(Robyn,2007). This may take a bilateral treaty or a multilateral convention. Glahn (1970) on his partpointed out that in modern times a state may decide to voluntarily surrender a fugitive for justice, but the only legal right to demand for such surrender can only exist where there is existing treaty or treaties. Therefore, for an offence such as terrorism to be regarded as extraditable case, it must be regarded as a crime under the laws of the requesting and requested parties. This is what Bassiouni (1974) regarded as the surrender of one state to another, a person accused or convicted of a crime "by virtue of treaty reciprocity" between the respective states. That means, each state must mutually reciprocate that right as a sovereign state.The general principle, therefore, becomes established that without some formal authority either by treaty or statutes, fugitive criminals, and terrorists will not be surrender nor will their surrender requested (Abegunde, 2014). However the issue of human rights is also sacrosanct in the pursuit of extradition of fugitives' criminals and terrorists which encumbered extradition process and the need for effective cooperation between nation states becomes a challenge and a bone on the extraditing states and the global community in contending these diverse conditions of extradition treaties and laws. Against this background, this studyis in response to the apparent helplessness of these laws and treaties in management of crimes and combating terrorism. Hence there is the need to peep into and proffer solution to these global security dilemmas.

\subsection{Aim and Objectives of the study}

The main aim of the study is to examine the role of extradition treaties in management of crime and combating terrorism, while the specific objectives are to:
I. study the nature and extent of extradition treaties and laws in management of crime and combating terrorism,

II. identify those issues and challenges of extradition laws and treaties in management of crime and combating terrorism, and

III. Proffer managerial strategies and solutions that will enhance extradition laws and treaties in the management of crime and combating terrorism.

\subsection{Research Questions}

The following research questions were able to guide this study:

I. What are the nature and extent of extradition treaties in management of crime and combating terrorism?

II. What are the identifiable issues and consequences of extradition treaties and failure in management of crime and combating terrorism?

III. What are the management strategies that can be llnemployed to ensure effective implementation of extradition treaties in management of crime and combating terrorism?

\subsection{Methodological Review}

This study uses explorative, comparative and qualitative analyses to x-ray the relationship between the role of extradition treaties and laws in management of crime and combating terrorism. Hence, this study relied purely on secondary sources of data collection such as documents sourced from journals, articles, books, gazettes, correspondence, and internet sources etc.

\subsection{Theoretical Analysis}

The theory that was adopted in this study is "Double Criminality theory" which was conceptualized by Jay Treaty of 1794, and which concerned extradition requests between the US and UK, and popularized by Jonathan in 1992 and Lech Gardeodei in 1993. In their opinions the principle of double criminality is traditionally bound with institutions of international law, which employs a range of double conditions or reciprocity or replicate agreement. They pointed out that double criminality also known as dual criminality is a necessary condition for international extradition treaties that requires the conduct of the 
prospective extradited persons to constitute an offence in the jurisdiction of both requesting and the receiving state. In a clearer form it states that a suspect can be extradited from one country to stand trial for breaking a second country's law only if a similar law exist in the extraditing country (U.S Legal Department Definition). What this connotes is that the requesting and requested states must have laws prohibiting such act as crime in both countries which must be mitigated.

The common dominator of which is the requirement that two legal systems share a certain set of values or legal prescriptions. International laws use such terms as double punishability, the double possibility of criminal proceeding which requires double possibility of the execution of penal judgement (Lech, 1993). The double criminality theory is informed by its integrative nature of legal provisions of both extraditing states. Its emphasis is on the need to involve or recognise laws and offence of both states. It means that for a crime to be extraditable, it must have violated both the extraditing and the requesting states' laws. While the theory cannot be said to be flawless, it fills a reasonable gap and presents a point of departure for this study.

\subsection{Empirical Review}

\subsubsection{The Nature and Extent of Extradition} Treaties in Management of Crimes and Combating Terrorism

Most nations of the world have cooperated in issues relating to crime control by exchanging fugitive criminals. These exchanges were made possible either through a formal agreement between them such as treaties or by informal means such as reciprocity. In modern times, international law knows no other right to extradite apart from treaties. A state may voluntarily surrender a fugitive offender for justice, but the only legal right to demand for such surrender can only exist where there is existing treaties (Glahn, 1970). That is why official opinion in the United States denies the existence of any authority to surrender a fugitive in the absence of a treaty. This implies that an offence can only be regarded as extraditable offence if the domestic laws of the contracting parties regarded the offence as a crime under their laws. This is why Umezurike (1972) opines that without formal authority either by treaty or by statute, fugitive criminals would not be surrendered nor would their surrender be granted. He also pointed out that extradition can only be done through the process of "reciprocity" or under "treaty", where one state surrenders to another at its request, on the ground of existing collaboration. In the same manner, Bassiouni (1974) refers to extradition as the surrender of one state to another, a person accused or convicted of a crime "by virtue of treaty reciprocity between the contracting states". He argued that extradition treaties do address or attempt to resolve crimes committed by an individual in one of the countries and who takes refuge in another or the offender from one country who commits a crime in another country and slips back into own country (Bassiouni, 1994).

The only two most important forms that distinguish modern extradition treaties according to Shearer (1971) are; the conscious purpose, openly and regularly pursued to restore a person to an authority competent to exercise jurisdiction over him; and the observance of a body of rules imposed by international and municipal law, governing both the pre- requisites for and the consequences of extradition. Shearer (1971) has also classified extradition treaty as having an "enumerative" or "eliminative methods". A treaty that follows the enumerative methods lists defined the crime for which extradition will be granted. In the eliminative or no list method, extradition offences are defined in terms of their punishability according to the laws of the countries by a minimum standard of severity. The eliminative method appears to be the more popular of the two methods in the recent years. Despite the differences between the two methods, both methods observed the rule of "double or dual criminality principle of extradition" that required that an act shall not be extraditable unless it constitutes a crime according to the laws of both the requesting and the requested states (Shearer, 1971).

Sunil (2000) on his part posits that extradition is the formal process by which an individual, the person to be extradited, is surrendered from the asylum state where he is located to the requesting state in order to face prosecution, or if already convicted to serve a sentence. For Abegunde (2014) extradition is the surrender of a criminal from one sovereign authority to another. It is the process of returning somebody accused of a crime by a different legal authority for a trial or punishment. According to him, there is a little acceptance of the notion of "sanctuary" in international law. Hence, if an alleged offender is in a 
territory other than the state seeking to exercise jurisdiction, the only lawful method of seeing his return to stand trial is to request for extradition.

Extradition treaties according to Petersen (1992) are based on the principle of mutuality, with every offender extradited to a requesting state; the requesting state's chances grow in reciprocity. This implies that a desirable "by- product" of extraditing offenders is that doing so reduces international tensions; and the requested state acknowledges the high stake the requesting state has in prosecuting an offender whose victims presumably lives or lived within the borders of the requesting state's territory (Petersen, 1992). In other words, extradition treaties function significantly in the suppression of terrorism and as counter-terrorism measures. Though, extradition treaties do not play covert or more roles within the grand scheme of international cooperation in countering or combating terrorism and at the same time reducing, and completely tend to eliminate the number of "safe havens" for terrorists. This implies that extradition treaties have evidently reduced the number of "safe harbour states" to which terrorists can retreat after an attack (Petersen, 1992).

Since the bombing of the World Trade Centre in New York and the Pentagon in the suburb of Washington, D.C, the fight against terrorism assumed a noncomparable global cooperation. The campaign against all forms of terrorism led by the United States of America (U.S.A) immediately after the attacks on the State revived and strengthened global collective security. Terrorism is no longer seen as a minor threat but as an incredible act carried out by clandestine and dissident groups, thus must be tackled with all forms of intensity globally. The quest to prevent or completely eliminate the spread of global terrorism led to a pervasive world-wide war with military countermeasures (Christopher, 2003; Imobighe, 2006).

In Afghanistan, for example, the excessive use of military countermeasures to fight or combat terrorism led to the sacking of the Taliban Government, and in other places such as Palestine in the Middle East. It has also led to destruction of towns, cities and refugee camps and which unfortunately resulted to the death of hundreds of thousands of innocent lives (Imobighe, 2006:1). This is as a result of the states not complying with extradition treaties, hence most states became safe haven for terrorists. That is why the affected states like the United States, Britain, France, etc. have no option than to attack any state collaborating with terrorists. This brings international crisis.

The most devastating fact about this is that, while mainstream counter-terrorism campaign with purely militaristic focus is being led by the United States, some Governments are hiding under the cover of antiterrorism campaign to attack their political enemies and opponent so as to silence them completely. To this group the campaign against terrorism through "extradition" has been hindered to hunt and track down their perceive enemies. Christopher (2003) opines that the "law enforcement approach" with its strategic tool to combat transnational terrorism as the apprehension, persecution, prosecution, and punishment of persons who perpetrate or conspire to commit such criminal acts remains the most appropriate rather than the "law-of-armed conflict" approach.

To this end, global cooperation and collaboration is required to apprehend, prosecute, and punish those who perpetuate or conspire to commit criminal or terrorist acts. This is accepted as the only diplomatic channel and feasible legal means to combat terrorism. This reality may be a plausible explanation for a global cooperation or collaboration to manage all forms of crime and combat terrorism through "bilateral", and "multilateral" treaties of extradition.

\section{2:2 Identifiable Issues and Challenges of Extradition Treaties in Crime Management and Combating Terrorism}

Extradition practice plays a significant role in the suppression of crimes and is one of the mechanism of anti and counter terrorism measures. It encourages states to request or hand over to one another suspected or convicted criminals who have fled. In this respect, Rebane (1996) asserted that for extradition to occur a formal extradition request will be made to the requested state which then sets in motion the requesting state to begin judicial action. Rebane also observed that in common law, the requested state have the authority to decide whether to extradite or not depending on the political interest of the state, this is a contending issue.

Meanwhile, a lot of legal technicalities are involved in the process of extradition between two states or international bodies, for instance most states require at least minimal judicial review of the extradition process. Common law countries requires the requesting state to establish probable cause, while 
Civil law states considered the formal request prima facie evidence sufficient enough to grant extradition if all other treaty obligation is satisfied ( Rebane,1996). For a nation to prove all these conditions, it requires long and diligent approach and technicalities, which justice delay is justice denied.

Glahn(1970) pointed out that a request for the surrender of an alleged fugitive offender must be presented to the foreign state through the diplomatic agent of the seeking government, and when such request is received, the foreign government must initiate an investigation through its judicial agencies to determine whether there is sufficient evidence, in accordance with the local law to warrant an arrest of the fugitive offender, if sufficient evidence is submitted and in accordance with the local law the fugitive criminal would be held, pending the seeking state's agents' arrival. The agents on receiving the offender extradite him to the state in which the crime was committed.

Despite the significance of this provision to extradite an offender, there are some exceptions and limitations to extradition law. These exceptions, limitations or $i$. identifiable issues and challenges can be best ii. discussed under the following subheadings as enunciated by Rebane(1996), and Abegunde(2014).

\section{Doctrine of Dual/Double Criminality:}

This is a significant principle of extradition. It iv. requires that extradition would not begranted to the seeking state unless the offense committed by the offender is contained inthe domestic or municipal laws of both the seeking and the asylum state. This implies that, unless the offence allegedly committed by a fugitive constitutes an offence in both the extraditing seeking state and the asylum state, the alleged offender would not be extradited.

\section{The Speciality Principle:}

This is also a significant principle of extradition. It constitutes an impediment to extradition laws. An extraditing country under this principle is prevented from presenting an individual for crimes other than those specified in the extradition request; this is an absolute or total restriction to extradition. It implies that an alleged offender may not be tried for even a lesser offence if it is not contained or conversed in the extradition request.

\section{Doctrine of Extra-Territoriality:}

This principle continues to limit extradition laws and practices. According to Rebane (1996) extraterritoriality is the right of nations to control activities within their domestic jurisdiction irrespective of whether the crime cut-across border or it affected other countries. He emphasized that nation's guard or protects their rights and any nation that infringes on or flouts these rights present a threat to the international system's integrity, that when one nation utilizes "unilateral" methods to capture a fugitive, international pressure can force that nation- state to reverse its action. In other words, the offending nation suffers additional fines and reprimands.

\section{Doctrine of Political offence:}

This form of offence according to Glahn (1970) is an act which in itself is a common crime and that which requires a predominantly political character because of the circumstances and motivations under which it was committed. For an offence to be political in nature it must satisfy the following conditions;

It has to be an overt (open) act,

It has to be carried out in support of a political uprising,

The up-rising has to be connected with a dispute or struggle between two groups or parties in a state as to which one was to control the government.

In other words, Rebane (1996) identified three main tests for identifying legitimate crimes since there is no clear definition of relative political offence. These tests are:

a. Political Incidence Test: This test examines whether criminal acts were part of or incidental to a political purpose or struggle such as war, revolution or rebellion.

b. Political Motivation Test: This test balances the ideological motive of the offender against her acts in proportion to the political gains sought. The greater the degree of violence involved, the more closely related the political goals must be.

c. Injured Rights Test: Political crimes are those crimes that affect the political organisation of a nation while common crimes are those crimes that affect rights other than those of the nation. This approach, therefore, grants relief to those individuals accused of pure political crimes (Rebane, 1996). 
However, there are a lot of other issues and challenges that are inherent in extradition of criminals and terrorists. These issues and challenges are so enormous that the globe may subdue in it if not checked. For instance, for a state to attain jurisdiction for extradition, it has to follow some lay-down procedures or steps which are cumbersome for some state to meet, hence create lacuna in arresting, apprehending, and prosecuting the said criminals. First is that the party concern must first determine whether the requesting state's domestic law covers the offence or not, that is, whether there are grounds for exercising national jurisdiction or not. Secondly, the sovereign state must also ascertain whether it may proscribe (forbid or prohibit) such conduct extraterritorially under international legal rules that may be in tandem with current reality. In view of this, Bassiouni (1987), and Jonathan (1992) enumerated certain extraterritorial conditions that are inimical for the requesting state and the requested state which include:

\section{(i)}

\section{Territorial Basis of Extraterritorial Jurisdiction}

The territorial basis of extraterritorial jurisdiction according to Jonathan (1992), allows a country to enact domestic laws which prohibit certain conduct committed within its territory. This implies that a proper interpretation of territorial jurisdiction requires the act committed by the alleged offender to be within the territory of the requested state. It determines jurisdiction according to the location of the crime and holds that a state may punish crimes committed within its territory. Jonathan thus identified a variant of this principle. He stated that some states have adopted more liberal interpretations of the territorial principle of jurisdiction, such as "Subjective" and "Objective" territoriality. Subjective territoriality according to him provides that, if one of the elements of the crime is committed within the territory of the requesting state, that state has jurisdiction to prosecute. The Objective territoriality allows the prosecution of an individual engaged in conduct proscribed by the requesting state even when the act occurred outside the state (Jonathan, 1992).

\section{(ii) Nationality Basis of Extraterritoriality Jurisdiction}

The Nationality principle of jurisdiction states that the citizens of a state are entitled to protection by the state even when they are outside the state's territorial boundaries. The purpose of this is that from the perspective of international law, nationals of a state remain under the state's personal sovereignty and their allegiance to it, even though travelling or residing outside its territory (Jonathan, 1992). In this regard, the state has legal authority under international and domestic law to assert criminal jurisdiction over actions of one of its nationals deemed criminal by that state's law. When this basis is recognized by both the requesting and requested states, jurisdiction is asserted against the offender. The alleged offender therefore can be convicted by their nation of origin when they commit such offences abroad.

\section{(iii) The Protective Basis of Extraterritorial Jurisdiction}

This form of jurisdiction exists when an extraterritorial offence has or potentially has an advance effect on or poses a danger to a state's security, integrity, sovereignty, or governmental function (Jonathan, 1992:217). It concerns acts abroad that are considered pre-judicial to the state's security interests. Under this principle, a state may exercise jurisdiction over certain acts that take place outside its territory, when such acts threaten the security, territorial integrity, or political independence of the state. This means that the protective principle permits government to prosecute nationals of other states for their conduct outside the offended state $\left(13^{\text {th }}\right.$ UNCongresson CrimePreventionandCriminalJuri sdiction,2015). The only issue here is that the requested state may also exercise their right without following the requesting state's rules.

\section{(iv) Passive Personality Basis of Extraterritorial Jurisdiction}

The Passive Personality Principle gives a state extraterritorial jurisdiction over offences committed against its nationals irrespective of where the crime occurs. According to Jonathan (1992:218), this principle conversely provides that a nation has jurisdiction over those who commit crimes against its citizens while they are abroad. This means that jurisdiction is based on the nationality of the victim. The problem here is that what may be crime in the requested state may not be crime in the requesting state, so to balance this issue requires a proper arrangement which may be cumbersome to both states. 
(v)

\section{Universality Basis of Extraterritorial Jurisdiction}

Bassiouni (1987) attempted to spell out the rationale for the basis of universal jurisdiction. He opines that some offences due to their very nature, affect the interest of all states even when committed in a given state or against a given state, victim, or interest. Such offences according to him may even be committed in an area not subject to the exclusive jurisdiction of any state such as the "high see", "air space" or "outer space". The gravity of such offence must be intensive and constitutes a violation against mankind before universal jurisdiction is adopted. The crime must be universally condemned before this form of jurisdiction is applied. Therefore, any state in which such offender is caught or captured can exercise jurisdiction over such offender. This means that any state that caught or captures the offender may prosecute and punish the offender on behalf of the world community. This jurisdictional theory also applies to acts such as piracy, genocide, and other forms of war crime including terrorism. The problem with this principle is that there is the possibility of a clash of interest or conflicting interests on the part of the states since jurisdiction is universally admitted.

\subsubsection{Management Strategies that Enhances Extradition Treaties for Crime Management and Combating Terrorism}

It is pertinent to note here that all these doctrines, issues and exceptions of extraterritorial jurisdiction contradicts one another to the extent that nations invoke the plausible one to the detriment of others and uses such clarity or narratives to explain why they did it; hence extradition treaties need to be reformed to enable current or contemporary security issues to be inculcated or remove in other to boast national and international security. Therefore, these strategies should include:

(i) There should be robust political will among international bodies to influence proper extradition rules on all nations,

(ii) Proper categorization of crime must be enlisted as crime against international body and be tried in a special international court located at each state, zone or region that people could litigate such cases. By this, states will not have power to inhibit the prosecution process of such offender'

(iii) In order to remedy the limitations on extradition rules and practices nations should succumb to the rights and authoritiesof international bodies in dealing with issues of double or dual criminality, specialty and extraterritoriality principles,

(iv) States that prove stubborn in extraditing offenders must be treated as conspirator of international crime and serious sanction be placed on them and those in authority be banned or not to travel out or declares personal non-grata,

(v) Any act of terrorism committed outside unclaimed territories or international territories should be drafted as crimes against United Nations and should be prosecuted as such,

(vi) Extradition laws should be made explicit or clearer by the United Nations relevant agencies to the individual states and should be incorporated or domesticated by member states for them to be more effective,

(vii) United Nations should set-up institutions that have its mandates to enforce all possible extradition cases,

(viii) Proper sanctions and punishment of offending countries or nations must be properly enshrined and leaders of such countries should be personally punished.

\section{CONCLUSIONS}

In conclusion, this study has tried in its modest attempt to examine the relationship of the role of extradition treaties in management of crime and combating terrorism. Abundant evidence shows that the nature of extradition treaties sprung out of the nature of increase in transnational threat and globalization which results to increase in crime that affect the globe generally. More so, the great challenges of nation building and insecurity has necessitated the need for robust extradition laws and treaties. This reality is responsible for global insecurity as a result of legitimacy scribes between extraditing states. However there is no doubt that a far reaching resolution and strategy that will cushion these ugly situations is established with these studies concerning the roles of extradition treaties in management of crime and combating terrorism.

\section{REFERENCES}

1. Abegunde, B (2014) Extradition under International Law: Tool for Apprehension of fugitives. Journal of law, policy and globalization, 22: $117-127$. 
International Journal of Trend in Scientific Research and Development (IJTSRD) ISSN: 2456-6470

2. Adeyemo, D. (2012) Fighting Terrorism in Nigeria. The Nation Newspaper, August 1, 2012. In Aderonke, M (2015) Terrorism and Counter Terrorism in Contemporary Nigeria: Understanding the Emerging Trends in the Journal of Policy and development studies. Vol. 9, No. 4, August 2015.

3. Bassiouni, C. M. (1974) International Extradition and World Public Order, Dobbs, Terry N.Y. AN. Sil Thriff: Leyden Oceanic Publication.

4. Bassuouni, C. M. (1987) International Extradition: United States Law and Practice $\left(2^{\text {nd }}\right.$ ed)

5. Christopher, C.J. (2003) International Extradition and Global Terrorism: Bringing International Criminals justice, 25 hoy, L. A Int'1 \& Comp. L. Rev. $\quad 493 . \quad$ Available http://digitalcommons.imu.edu/ilr/vol25/iss3/5

6. Glahn, V.G. (1970) Law among Nations: An introduction to Public International Law $\left(2^{\text {nd }}\right.$ ed). London:MacMillan.

7. Imobighe, T.A. (2006) Rethinking Terrorism and Counter-Terrorism.In Imobighe, 1 te $T$. atiA \&Egwavoem, A.N.T (ed). Terrorism and CounterTerrorism: An African Perspective. IbadanNigeria:Heineman Educational Books PLC.

8. Jonathan, O.H (1992) International Extradition: Issues arising under the Dual Criminality Requirement. Available at: http:/digitalcommon.law.byu/lawreview/vol.1992 /iss 1/4.Retrieved3/02/2017

9. Petersen, A.C (1992) "Extradition and the Political Offense Exception in the Suppression of Terrorism."Indiana law journal: Vol 67: ISS.2 Article 6. Available at: http://www.respository.lawindiana.edu/ilj/vol67/is s3/6

10. ebane, K, (1996) Extradition and Individual Rights. The need for an international Criminal Court to safeguard individual rights. Fordham University School of law International Journal 3(2): 9- 17

11. Robyn, Z.T. (2007) The Impact of the Bill of Right on Extradition. A dissertation submitted in partial Fulfilment of the requirements for the degree of Magister Legum in the Faculty of Law at the Nelson Mandela Metropolitan University, South Africa.
12. Sunnil, K.G (2000) Extradition Law and International Criminal Court. Available at: http://scholarship.lawsberkeley.edu/bjcl/vol.3/iss7

13. Shearer, I.A (1971) Extradition in International Law. Manchester: University Press.

14. Umozurike, U. O (1972) Introduction to International Law. New York: University Press.

15. Webster's University Dictionary and Thesaurus.

16. Wikinson, P (2001) Terrorism versus Democracy: The Liberal State Response. London: Frank Case. P. 106

\section{OFFICIAL DOCUMENT}

1. Convention for the Suppression of Unlawful Acts against the Safety of International Maritime Navigation, March 10, 1988, S. Treaty Doc .No. 101 - 1. 1678 U.N.T.S 222 (Entered into force March, 1, 199) [Hereinafter 1988 SUA Convention].

2. Federal Bureau of Investigation (2006) Terror 2000. Available at:

http://www.fbi.gov/publication/terror2000$2001 \mathrm{htm}$ Retrieved on 8th August 2016.

3. International Convention against the Taking of Hostages. Dec. 17. 1979, T.I.A.S No 11, 081,1316U.N.T.S 204 (entered into force June 3, 1983).

4. International Convention for the Suppression of Terrorist Bombings. S. TREATY DOC. NO. 1066(1997) [Entered into force May 2001).

5. International Convention for the Suppression of the Financing of Terrorism, SEN. TREATY DOC. NO.106 - 49 (Dec 9, 1999) (entered into force April 10, 202) [hereinafter Terrorism Financing Convention.

6. OAU Convention on the Prevention and Combating Terrorism, 199, p.3

7. Montreal Convention for the Suppression of Unlawful Act against the Safety of Civil Aviation, September 23. 1971, 24 U.S.T 564, 974 U.N.T.S. 177.

8. The Hague Convention for the Suppression of Unlawful Seizure of Aircraft. December 16, 1970 22 U.S.T 1641, 860 U.N.T.S. 105.

9. $13^{\text {th }}$ United Nations Congress on Crime Prevention and Criminal Justice: Combating Transnational Organised crime through Better 
International Cooperation, Doha. 12 -19 April 2015.Available at: www.un.org/en/events/crimecongress2015.

10. UN General Assembly Resolution of 1999.

11. United Nations Report (2004). "A More Secure World: Our Shared Responsibility." Report of the High - Level Panel on Threats, Challenges and Change.

12. U.S. Legal Department Definition. Available at: Wikipedia http://en.m.org.wikidouble. Retrieved:

$3 / 2 / 2017$.

13. Protocol for the Suppression of Unlawful Acts of Violence at Airports Serving International CivilAviation, Feb. 24.1988, ICAD DOC. 9518. Available: http://www.uncp.org/odccp/terrorismconvention-airports.html 